\title{
Students' Attitude Toward Character Building Courses at Bina Nusantara University
}

\author{
Benny¹, Oki Hermawati², Anggaripeni Mustikasiwi ${ }^{3}$, Wylen Djap4, Dadang Irawan ${ }^{5}$ \\ 1,2 Bina Nusantara University, 3,4,5 Pelita Harapan University \\ E-mail: benny004@binus.ac.id, oki.hermawati@binus.ac.id,anggaripeni.mustikasiwi@gmail.com, \\ wylen230499@gmail.com,irawan.150175@gmail.com
}

\begin{tabular}{|c|c|}
\hline Article Info & Abstract \\
\hline $\begin{array}{l}\text { Keywords: } \\
\text { Character; } \\
\text { Character Building; } \\
\text { Attitude; } \\
\text { Pancasila; } \\
\text { Civics; } \\
\text { Religion. }\end{array}$ & $\begin{array}{l}\text { Character development is required for students so they can bring benefits to society in } \\
\text { the future. Character development in Bina Nusantara University has been carried out } \\
\text { since } 2001 \text {. Character development is in the form of } 3 \text { compulsory classes using values } \\
\text { from Pancasila, Citizenship, and Religion. To improve continuously, it is necessary to } \\
\text { find out students' attitudes toward character-building courses they had taken. This } \\
\text { research measures students' attitudes towards the importance of character } \\
\text { development, their favorite character-building course, how character-building courses } \\
\text { influence their character, and whether applicable and relevant to everyday life. The } \\
\text { result of the research shows students understood the importance of character } \\
\text { development, the Character Building: Religion course was their favorite. The Character } \\
\text { Building: Religion highly affects their character and is very applicable and relevant. } \\
\text { Character Building: Pancasila and Character Building: Civics has an influence on their } \\
\text { character, which are also applicable and relevant. The current state of Character- } \\
\text { Building courses is good but still has room to improve. By knowing how students } \\
\text { respond, further improvement can be more precise and effective. }\end{array}$ \\
\hline Artikel Info & Abstrak \\
\hline $\begin{array}{l}\text { Kata kunci: } \\
\text { Karakter; } \\
\text { Pendidikan karakter; } \\
\text { Sikap; } \\
\text { Pancasila; } \\
\text { Kewarganegaraan; } \\
\text { Agama. }\end{array}$ & $\begin{array}{l}\text { Pengembangan karakter diperlukan bagi siswa agar dapat membawa manfaat bagi } \\
\text { masyarakat di masa depan. Pengembangan karakter di Universitas Bina Nusantara } \\
\text { telah dilakukan sejak tahun 2001. Pengembangan karakter berupa } 3 \text { mata kuliah wajib } \\
\text { dengan menggunakan nilai-nilai Pancasila, Kewarganegaraan, dan Agama. Untuk } \\
\text { meningkatkan secara terus-menerus, perlu diketahui sikap siswa terhadap mata kuliah } \\
\text { pembentukan karakter yang telah diambilnya. Penelitian ini mengukur sikap siswa } \\
\text { terhadap pentingnya pengembangan karakter, mata kuliah pembentukan karakter } \\
\text { favorit mereka, bagaimana mata kuliah pembentukan karakter mempengaruhi } \\
\text { karakter mereka, dan apakah dapat diterapkan dan relevan dengan kehidupan sehari- } \\
\text { hari. Hasil penelitian menunjukkan bahwa mahasiswa memahami pentingnya } \\
\text { pengembangan karakter, mata kuliah Character Building: Religi menjadi favorit } \\
\text { mereka. Pembentukan Karakter: Agama sangat mempengaruhi karakter mereka dan } \\
\text { sangat aplikatif dan relevan. Character Building: Pancasila dan Character Building: PKn } \\
\text { berpengaruh terhadap karakternya, yang juga aplikatif dan relevan. Kondisi kursus } \\
\text { Pembentukan Karakter saat ini baik tetapi masih memiliki ruang untuk ditingkatkan. } \\
\text { Dengan mengetahui bagaimana respon siswa, perbaikan selanjutnya dapat lebih tepat } \\
\text { dan efektif. }\end{array}$ \\
\hline
\end{tabular}

\section{INTRODUCTION}

In the era of technological advancement responsible technology implementation requires good character. Knowledge and technical skills alone are not enough to make a person able to contribute to society. It takes a strong character, unyielding to achieve success, and a character with integrity so as not to be corrupted, According to Kupperman, a character is a normal pattern of thought and action, especially with respect to concerns and commitments in matters affecting the happiness of others or self, and most especially in relation to moral choices. According to Wynne, a character is a sign of how to focus on how to apply the value of goodness in the form of actions or behavior. So that character is the basis in moral thinking patterns that are applied in the form of actions that can affect themselves and others. The application of the character starts from the smallest scope, family to the world, quotes from Thomas Lickona.

Character education is one way of building character on students. Character education showed that it influences students' behavior even 
without teacher's supervision. This effect was confirmed in Indonesia as well.

Character development officially became part of Bina Nusantara University in 2001. CBDC (Character Building Development Center) was established to develop and oversee the character development courses in Bina Nusantara University. From 2001 to 2021, character building in Bina Nusantara University has undergone several changes. Bina Nusantara University currently has three character-building courses. These courses aim to develop students' character so that graduates of Bina Nusantara University who have technical expertise and skills also have good morality and conscience. In general, Bina Nusantara graduates will be able to make the world a better place.

These three character-building courses currently use 3 sources of value, namely Pancasila, Civics, and Religion. This is an approach taken so that the compulsory subjects that are regulated by the Ministry of Education and Culture become something more interesting and useful. This approach also directly makes all Bina Nusantara University graduates get character development, Continuous improvement of character-building courses is something that Character Building Development Center is striving to do. Adjusting curriculum to world changes and different style of generation will ensure the character-building process produce a maximal result. By getting students' opinions, improvement can be focused on the right part and will be beneficial for future classes. This research focuses on student attitudes towards character-building courses given at Bina Nusantara University. How do character-building courses have an impact on students? What is the application and relevance in life? These opinions will provide inputs to CBDC to improve character-building curriculums.

\section{METHOD}

This study uses a qualitative descriptive method. Data was retrieved by an online questionnaire using the Google Form platform for Bina Nusantara University students in 2021. The questionnaire was distributed to two undergraduate programs, regular and global classes from Alam Sutera and Bekasi campuses. The majors of students who received the questionnaire were International Business Management, Business Hotel Management, and Accounting Technology. Students who filled out the questionnaire were students who had received all three CB courses with a total of 150 respondents.

The questionnaire was divided into 4 parts. The first part is a general section that takes students' opinions on character development in general and which one is the most preferred character-building course. Parts two to four are about the effects of courses on student character, level of applicability, and relevance in life. Parts two to four are divided for the Character building subjects Pancasila, Citizenship, and Religion. All questions are in 4-point Likert Scale score 0 to 3. Score 0 being the lowest or no impact or importance and Score 3 for being the highest impact or importance.

\section{RESULT AND DISCUSSION}

\section{A. Character Building}

The following figure is the result of responses about student attitudes towards character development in general. Out of 150 respondents, $72.7 \%$ of respondents stated that character development is very important, $26 \%$ stated that character development is important and only $1.3 \%$ of respondents stated that character education is only slightly important. No one thinks that character education is not important. $(\mathrm{m}=2.71, \mathrm{SD}=$ $0.48, \min =1$, $\max =3$ ).

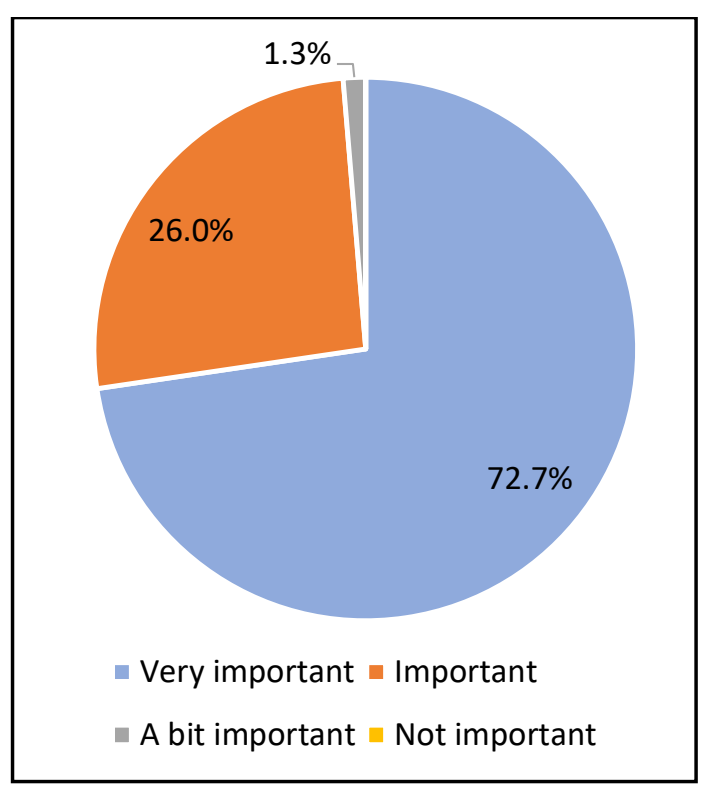

Figure 1. Character Building Importance

From these results, students realize that character education is very important. This indicates that students consider characterbuilding courses as very important and do not consider Character building courses as mandatory courses that are taken only as a formality. This awareness is important 
because it relates to how students undergo character-building courses so they can internalize the values obtained from character-building courses as their character.

\section{B. Favorite Subject}

Of three character-building courses, CB Religion was the favorite of $80 \%$ of the respondents, followed by Pancasila at $12 \%$ and Citizenship at 8\%.

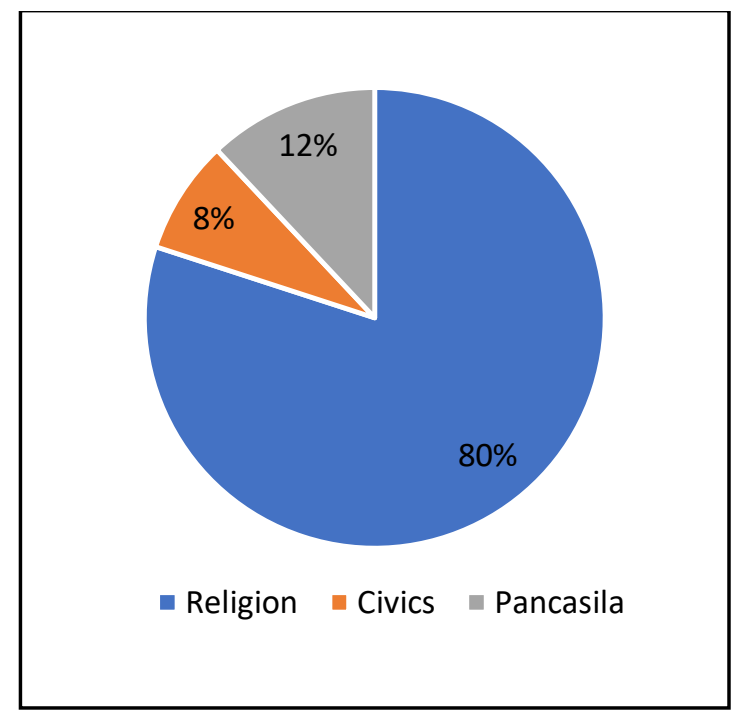

Figure 2. Favorite Subject

In this section, we look at the personal subjectivity of each student towards their preferred character-building course. There are two interpretations of this data why Religion gets the most portion with $80 \%$ of respondents. First, that the Character Building: Religion course has materials that are related to daily life. Second, the Character Building: Religion course is new compared to Pancasila and Civics which they have been taken repeatedly from elementary, junior high, and high school, so they are already exhausted. In addition to the religious CB, students study various religions that were previously unknown from various perspectives.

\section{Character Building: Pancasila}

In the Character Building: Pancasila course, $24.7 \%$ think that this course is very influential on its character, $63.3 \%$ think it is influential, $11.3 \%$ think it has little influence, and $0.7 \%$ think it does not affect their character. $(\mathrm{m}=2.12, \mathrm{SD}=0.61, \min =0, \max =3)$

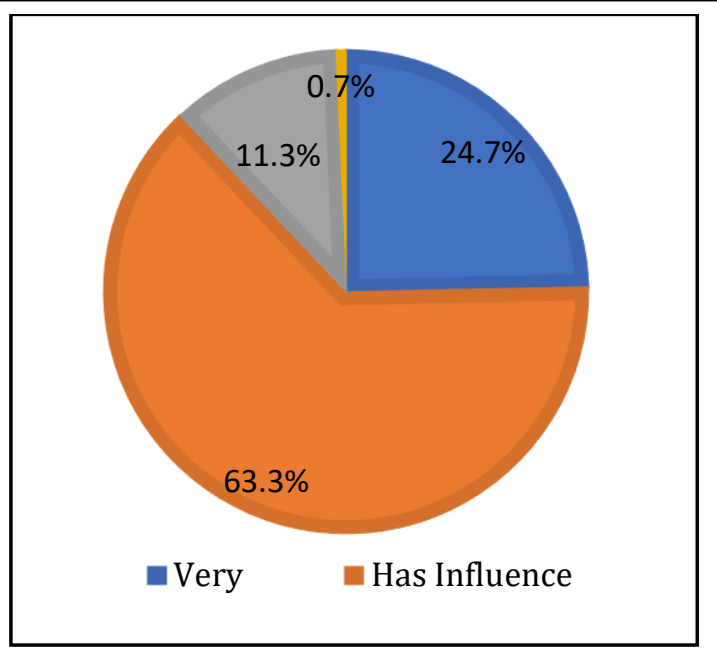

Figure 3. Character Building: Pancasila Influence on Character

For applicability and relevance in life, $26.7 \%$ think that Character Building: Pancasila is very applicable and relevant in life, $61.3 \%$ think it is applicable and relevant, $12 \%$ think it is slightly applicable and relevant, and no one thinks that CB Pancasila is irrelevant. $(\mathrm{m}=2.15, \mathrm{SD}=0.6, \min =1, \max =3)$

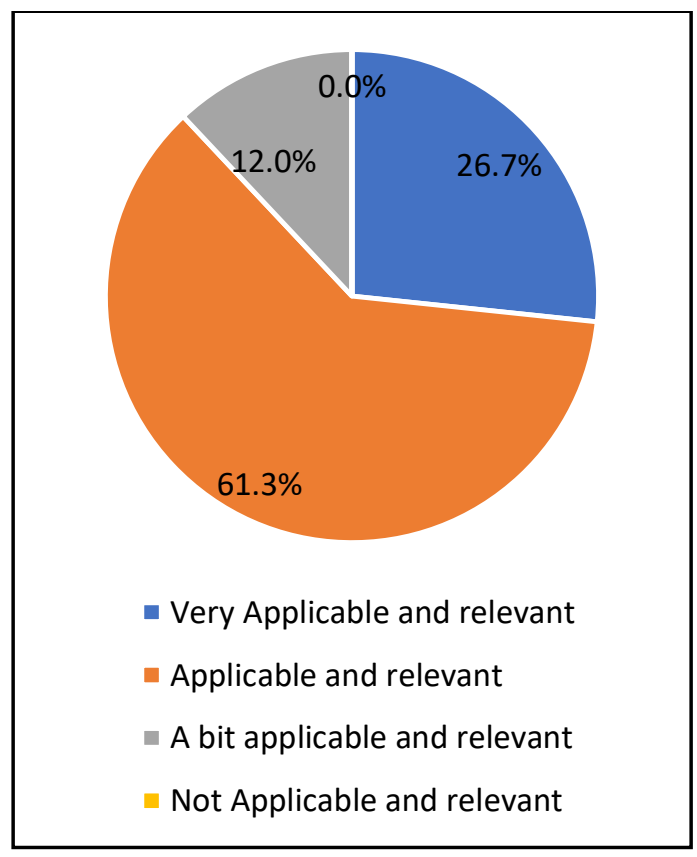

Figure 4. Character Building: Pancasila in Life

\section{Character Building: Civics}

Students think that $29.3 \%$ have a strong influence on their character, $64 \%$ think they have an effect, $6 \%$ think they have a little influence and $0.7 \%$ have no effect. $(\mathrm{m}=2.22$, $\mathrm{SD}=0.58, \min =0, \max =3$ ) 


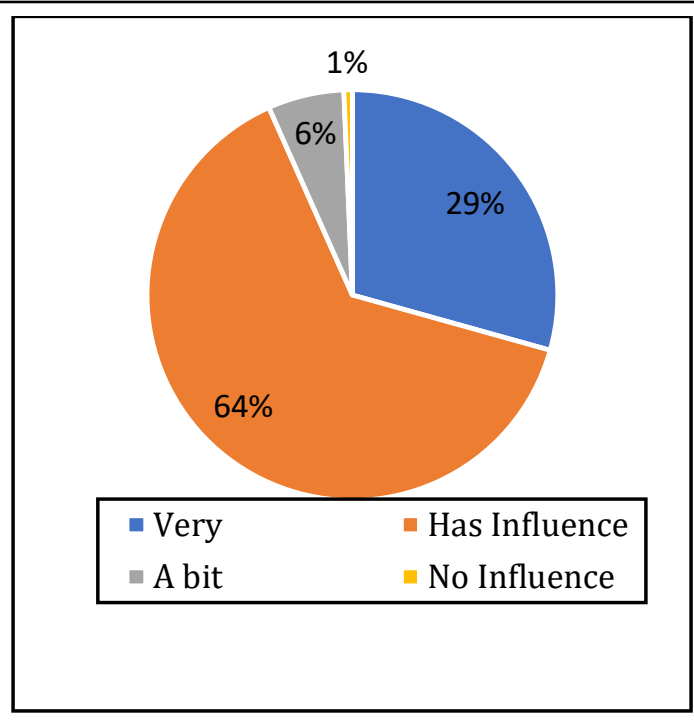

Figure 5. Character Building: Civics Influence on Character

The influence of Character Building: Civic on life got $29.3 \%$ of student's opinion that it is very applicable and relevant, $64 \%$ choose it is applicable and relevant, $8 \%$ is slightly applicable and relevant, and none thinks that it's not applicable and relevant. $(\mathrm{m}=2.19$, $\mathrm{SD}=0.56, \min =1, \max =3$ )

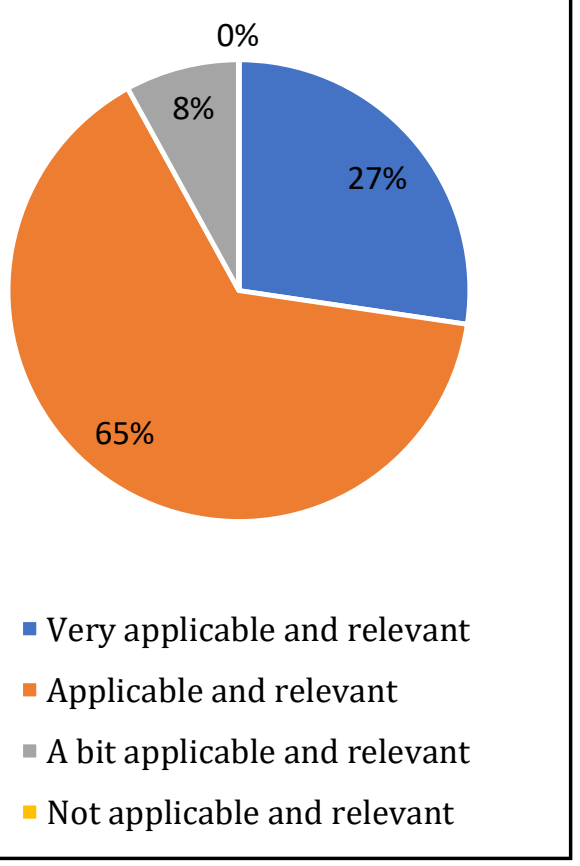

Figure 6. Character Building: Civics in Life

\section{E. Character Building: Religion}

In the Character Building: Religion, $56 \%$ of respondents answered that the Character Building: Religion was very influential on their character, $42 \%$ answered that it was influential, only $2 \%$ answered that it had little influence, and no one answered that it had no effect. $(\mathrm{m}=2.54, \mathrm{SD}=0.54, \min =1, \max =3)$

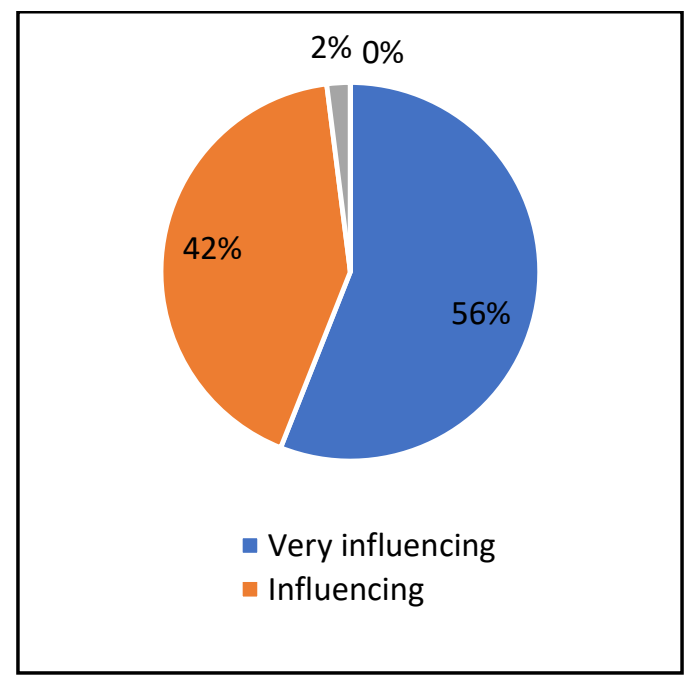

Figure 7. Character Building Religion on Character

For the applicability and relevance of Character Building: Religion in life, 50\% think that it is very applicable and relevant, $48 \%$ think it is applicable and relevant, and only $2 \%$ and no one thinks that it is not applicable and relevant. $(\mathrm{m}=2.48, \mathrm{SD}=0.54, \mathrm{~min}=1$, $\max =3$ )

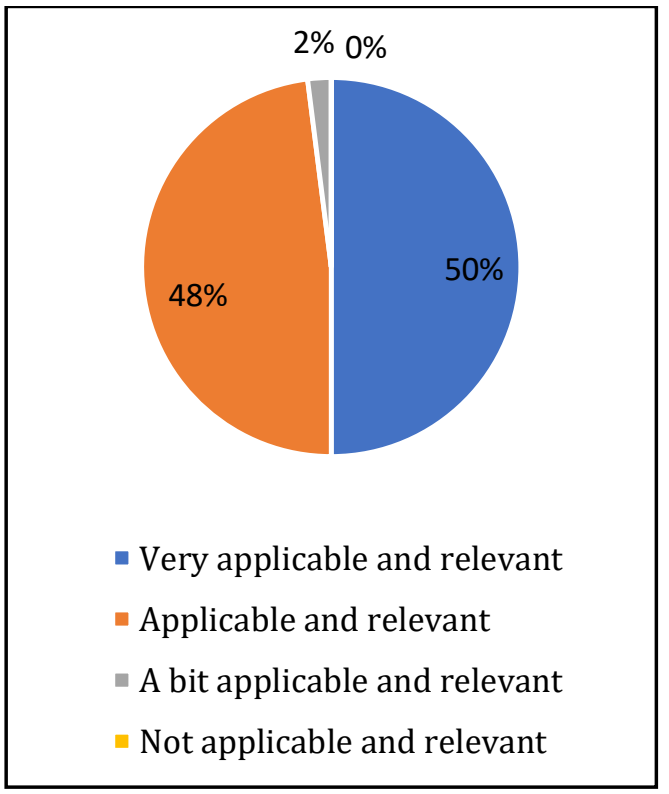

Figure 8. Character Building: Religion in Life Comparison

The following is a table of average comparisons between the three characterbuilding courses with mapping no influence and not applicable and relevant with numbers 
0 and 3 to be very influential and applicable \& relevant.

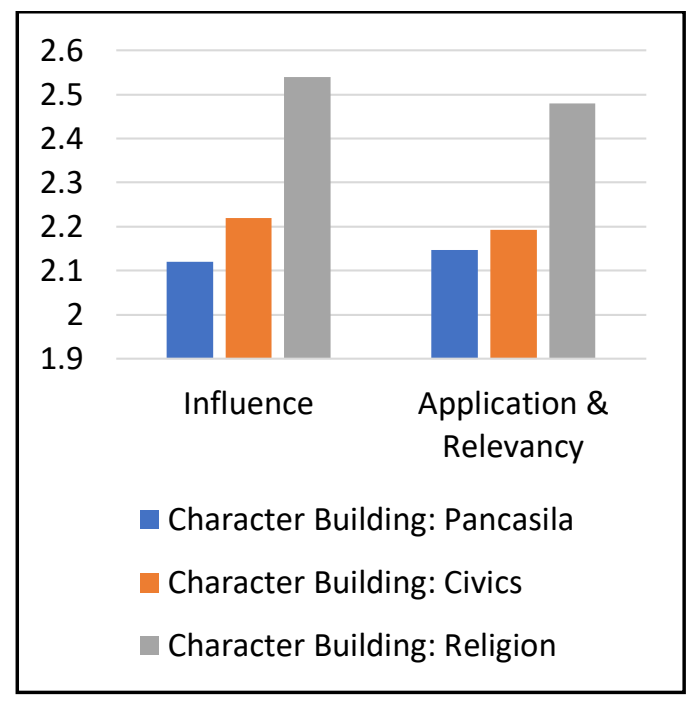

Figure 9. Average Comparison

Both questions show the correlation between application and relevance and influence on student's character. By having higher application \& relevance, the subject will have a better influence on student's character. So, to achieve character-building courses' objective is to increase the application and relevance of subjects in the courses.

Pancasila gets the lowest average then civics, and the highest is Character Building: Religion. This is because Pancasila is a deep philosophical theory so that its application value and relevance are lower than civics and religion which discuss life as citizens and as religious people.

\section{CONCLUSION AND RECOMMENDATION}

Awareness of the importance of character is very good for students. In general, this can be improved by socializing in the initial period when students join. By increasing this awareness, it will increase the effectiveness in seriousness in learning and turn into a person of good character. Having a good character will have a positive effect on the image of the campus and make a positive contribution to society and the country.

The Pancasila and Civics Character Building courses require adjustments to the content with a fresh approach so as not to cause boredom so that the positive values that you want to instill can be well internalized. If it is implanted properly, it will have a positive influence on the character of students. Relevant applications and examples need to be improved so that they can be directly seen in everyday life and can be applied directly.

The Character Building: Religion course has had a good impact as well as being relevant and applicable. However, it still needs to be adapted to the times and a wider focus on moral improvement. The focus values that will be developed can be adopted in new topics to enrich and increase the relevance and application of these courses.

Other focus values can also be added, for example from Institution/university values. Institutional values evolve according to the times and get revised so that these changes must also be reflected in the Character-Building course. With the synchronization of the values of the Institute and CB courses, the goals of the Institute will be achieved.

For further research, you can go deeper into the topics in the Character-Building course. Thus, it can measure more accurately, and precisely which topics can have an impact and level of applicability and relevance for students. Thus, it can be used as input when making revisions and improvements to the next curriculum.

\section{REFERENCES}

Bina Nusantara University. (2019, April). Character Building Development Center. https://binus.ac.id/characterbuilding/2019/04/character-buildingdevelopment-center/

Bradburn, N., Sundman, S., \& Wansink, B. (2004). Asking questions: The definitive guide to questionnaire design. San Fransisco: JosseyBass.

Branson, C. (2004). Effect of Character Education on Student Behavior. Master Theses. 1252. http://thekeep.eiu.edu/theses/1252

CBDC Team. (2019). Character Building: Agama. Bina Nusantara University.

CBDC Team. (2019). Character Building: Kewarganegaraan. Bina Nusantara University.

CBDC Team. (2019). Character Building: Pancasila. Bina Nusantara University.

Kemdikbud, Dikti. (2020) Pedoman Pelaksanaan Mata Kuliah Wajib Pada Kurikulum Pendidikan Tinggi (84/E/KPT/2020). 
https://lldikti1.ristekdikti.go.id/berkas/ke pdirjen-dikti-nomo-84 e kpt 2020tentang-pedoman-pelaksanaan-matakuliah-wajib-pada-kurikulum-pendidikantinggi.pdf

Kupperman, J. J. (1971) Character. New York: Oxford University Press. p 17

Marini, A. (2017). Character Building Through Teaching Learning Process: Lesson in Indonesia. Ponte International Journal of Sciences and Research Vol 73 No. 5.

Patella, C. (2003). The Effect of Character Education on Sudent Behavior. Theses and Dissertations.1351.

http://rdw.rowan.edu/etd/1351
Thomas, L. (2012). Education for Character: How Our School Can Teach Respect and Responsibility. New York: Bantam Books. p 50.

Wynne, E. A. (2015). Balancing: Character Development and Academics in the Elementary School. The Phi Delta Kappan 69 7 pp 424-426. 